\title{
ESPAÇO ESCOLAR E CIÊNCIAS: RELAÇÕES ENTRE AS PRESCRIÇÕES GOVERNAMENTAIS E O ENSINO
}

Luna Abrano Bocchi

Faculdade de Educação, Universidade de São Paulo

lunabocchi@gmail.com

\begin{abstract}
RESUMO
Tendo como pressuposto que o espaço não é neutro, sempre educa, o artigo problematiza as mudanças ocorridas no Colégio Marista Arquidiocesano de São Paulo entre os anos de 1900 e 1940, num momento em que gabinetes, laboratório e museu vinculados ao ensino de ciências foram constituídos. A análise considera os princípios educacionais e religiosos que orientavam a instituição, assim como as prescrições governamentais relacionadas à obtenção do título de equiparação. $\mathrm{O}$ estudo indica que o colégio reordenou o espaço escolar de acordo com uma proposta que valorizava o ensino prático e experimental - salas foram criadas e organizadas com mobiliários e artefatos próprios para as disciplinas científicas, possibilitando outras formas de circulação, interação e ensino.
\end{abstract}

Palavras-chave: Ensino de ciências. Arquitetura escolar. Processo de equiparação.

\section{SCHOOL PHYSICAL ENVIRONMENT AND SCIENCE: THE RELATIONSHIP BETWEEN GOVERNMENT GUIDELINES AND EDUCATION}

\begin{abstract}
Assuming that environment is not neutral - it always educates - the article problematizes the changes that happened at Colégio Marista Arquidiocesano de São Paulo between the years 1900 and 1940, when school science facilities (cabinets, laboratories, and museums) were built. The analysis considers the educational and religious principles that guided the institution, as well as the governmental guidelines related to obtaining the equivalence. The study indicates that the school rearranged its space over the years according to a proposal that valued practical and experimental teaching: the classrooms were created and organized using furniture, equipment and supplies designed for Science education, which enabled other types of circulation, interaction, and teaching.
\end{abstract}

Keywords: Science teaching. School architecture. Equivalence process.

\section{ESPACIO ESCOLAR Y CIENCIAS: RELACIONES ENTRE LAS PRESCRIPCIONES GUBERNAMENTALES Y LA ENSEÑANZA}

\section{RESUMEN}

Considerando que el espacio no es neutral, siempre educa, el artículo problematiza los cambios sucedidos en el Colégio Marista Arquidiocesano de São Paulo entre los años 1900 y 1940, en un momento en el que se constituyeron oficinas, laboratorios y museos vinculados a la enseñanza de 


\section{$(\mathrm{cc})$ EY}

las ciencias. El análisis considera los principios educativos y religiosos que regían la institución, bien como las prescripciones gubernamentales concernientes a la obtención del título de equiparación. El estudio señala que el colegio reordenó el espacio escolar conforme una propuesta que valoraba la enseñanza práctica y experimental - aulas fueron organizadas con muebles y artefactos propios para las asignaturas científicas, posibilitando otras formas de circulación, interacción y enseñanza.

Palabras-clave: Enseñanza de las ciencias. Arquitectura escolar. Equiparación.

\section{L'ESPACE SCOLAIRE ET LES SCIENCES: RAPPORTS ENTRE LES PRESCRIPTIONS GOUVERNAMENTALES ET L'ENSEIGNEMENT}

\section{RÉSUMÉ}

Reposant sur l'hypotèse que l'espace n'est pas neutre, car il eduque toujours, cet article analyse les changements intervenus dans le Colégio Marista Arquidiocesano de São Paulo au cours des années entre 1900 et 1940, à un moment où le cabinet de physique, le laboratoire et le musée ont été créés. L'analyse considère les principes éducatives et religieux qui régissaient l'institution, ainsi que les prescriptions gouvernamentales associées à l'acquisition du titre d'égalisation. La recherche souligne que le collège a réarrangé l'espace scolaire en conformité avec une proposition qui valorisait l'enseignement pratique - des classes ont été organisées avec des meubles et des objects spécifiques des disciplines scientifiques, en permettant autres formes d'interation et enseignement.

Mots-clé: Enseignement des sciences. Architecture scolaire. Processus d'égalisation.

\section{INTRODUÇÃO}

Ao afirmar que o espaço não é neutro, sempre educa, Viñao (2001) explicita uma dupla preocupação com o espaço e a educação. Escolhas são feitas, arranjos são propostos, pessoas circulam, interagem e aprendem com aquilo que foi planejado e explícito, mas também com o que foi silenciado, deixado num canto ou omitido. A ocupação e utilização do espaço supõem sua constituição como lugar, isto é, uma construção humana. Se o espaço é um elemento primordial quando consideramos os processos educacionais, assim também o é o tempo. Ambos, tempo e espaço, não só são mediadores básicos na construção histórica da infância, como categorias essenciais da cultura da escola. Enquanto elementos estruturantes da realidade escolar, expressam as características mais relevantes da educação formal nos discursos que instituem e nas práticas que geram (ESCOLANO BENITO, 2000).

Ao considerar as influências entre espaço e tempo, entretanto, Viñao (2001, p. 63) afirma que carecemos de memória em relação ao passado: 
O que recordamos são espaços que levam dentro de si, comprimido, um tempo. Nesse sentido, a noção de tempo, da duração, nos chega através da recordação de espaços diversos ou de fixações diferentes de um mesmo espaço. De espaços materiais, visualizáveis.

Ainda que as recordações variem conforme o que foi vivenciado por cada um, as escolas trazem à tona alguns traços comuns, característicos da tarefa à qual se destinam. A reordenação dos espaços escolares e a construção de lugares próprios para o ensino foi uma das mudanças empreendidas ao longo do processo de escolarização; de acordo com Gonçalves (2012, p. 30), tal transformação foi motivada por diferentes aspectos:

Institucionalização da educação como tarefa social, assumida pelo Estado; qualificação da força de trabalho assalariada emergente; universalização da necessidade de ensino; complexificação da vida social e especialização da cidade e dos espaços urbanos dentro e fora dela; hegemonia do pensamento positivista na educação; profissionalização dos professores; movimento sanitarista do final do século XIX; crescimento populacional das cidades.

Os prédios escolares e as salas de aula, mesmo que diferentes entre si, são reconhecidos pelas práticas escolares e universo material normalmente associados a esses lugares. O processo de ensino e aprendizagem deixa rastros, é constituído, veiculado, transformado e mediado pelos mais diversos artefatos, como problematizado por Lawn e Grosvenor (2005), Souza (2007) e Silva e Petry (2012). Lousa, livros didáticos, uniformes escolares, animais taxidermizados, prédios escolares, entre outros, já foram abordados em diversos estudos, sendo exemplos da cultura material escolar que, aos poucos, passa a ser desnaturalizada, vista em relação a aspectos sociais, culturais, políticos e econômicos.

O que mais nos interessa, neste estudo, são as marcas deixadas na escola num momento em que novos espaços para o ensino de ciências foram planejados e constituídos. No presente texto, enfocaremos os locais destinados ao ensino das disciplinas científicas no Colégio Marista Arquidiocesano de São Paulo, procurando entender os diferentes arranjos espaciais e mudanças empreendidas ao longo das primeiras décadas do século XX, tendo em vista as concepções educacionais e as prescrições governamentais. A possibilidade das escolas de curso secundário se equipararem ao Colégio Pedro II foi importante no estabelecimento de um modelo de ensino. O título de equiparação garantia que os alunos aprovados nos exames internos pudessem se matricular nos cursos superiores de caráter federal sem a necessidade de novas provas e, ao longo dos anos, 


\section{(c) $) \mathrm{EY}$}

foi valorizado pela direção do colégio paulista. Equiparado inicialmente em 1900, permaneceu assim até 1911, quando a equiparação foi suprimida pela Lei Rivadávia. O mecanismo só seria concedido novamente às instituições particulares em 1931, com a Reforma Francisco Campos.

Entendemos que os locais onde ocorriam as aulas foram configurados e usados de maneira a favorecer determinados aspectos voltados não somente aos conteúdos das disciplinas escolares, mas a uma forma de se comportar e de se relacionar entre os alunos, os professores e os objetos que compunham o ambiente. A análise de tais arranjos explicita pressupostos e significados sobre como o ensino e a aprendizagem eram entendidos num dado tempo e local, e evidencia as tensões entre aquilo que era esperado e o que de fato acontecia.

A análise documental histórica empreendida priorizou o processo de equiparação do Colégio Arquidiocesano e a publicação do Departamento Nacional de Ensino, Serviço de Inspeção dos Estabelecimentos de Ensino Secundário (1932), que aborda as normas e critérios estabelecidos para a concessão do reconhecimento oficial aos estabelecimentos de ensino secundário. A partir desses documentos, procuramos identificar as diretrizes governamentais em relação às salas de aulas especialmente destinadas ao ensino das disciplinas científicas, assim como compreender as mudanças efetuadas no espaço escolar em uma determinada instituição paulista. As fotografias que acompanharam a documentação do colégio foram igualmente importantes na presente análise ao evidenciarem a organização espacial e a composição das salas de aula, ainda que se reconheça o "filtro cultural" exercido pelo fotógrafo - presente tanto naquilo que elegeu registrar, quanto na organização visual dos detalhes que compôs o assunto e na exploração dos recursos oferecidos pela tecnologia (KOSSOY, 2009, p. 42). O recorte temporal de 1900 a 1940 justifica-se pela própria história do Arquidiocesano e compreende o período em que recebeu o título de equiparação, como também uma importante mudança no patrimônio edificado da instituição: a inauguração da nova sede em 1935.

\section{ENSINO RELIGIOSO E CIENTÍFICO: APROXIMAÇÕES E TENSÕES}

A história do Colégio Marista Arquidiocesano de São Paulo remonta à fundação do Seminário Diocesano, em 1856, e ao colégio instalado dois anos depois, que passou a receber alunos que não pretendiam seguir o sacerdócio. As instituições foram dirigidas pelos capuchinhos até 1879, quando o colégio passou a ser administrado pelos diocesanos. Os primeiros anos de 


\section{$(c)$ EY}

funcionamento são lembrados pela harmonia entre os princípios da fé e as verdades científicas, assim como pelo trabalho dos professores que "souberam criteriosamente levantar o edificio religioso junto ao scientifico" (SEMINARIO EPISCOPAL, 1906, p. 131). Em 1908, os Irmãos Maristas assumiram a gestão do colégio e, também nesse período, percebe-se a continuidade do discurso que procurava conciliar o estudo científico, a educação moral e religiosa. Os preceitos pedagógico e educacional dos Irmãos Maristas foram inspirados no Guia das Escolas e, ao contrário da ideia comumente atribuída ao ensino católico como sendo tradicional, Assis (2017) destaca que o texto traz referências a métodos pedagógicos próprios e modernos.

O documento dedica uma parte às lições de coisas, proposta que objetivava iniciar os alunos menores às ciências por meio do estudo de coisas familiares e previa "o conhecimento rudimentar das ciências físicas e naturais, transmitido por procedimentos intuitivos" (FURET, 2009, p. 243) ${ }^{1}$. Reconhecia-se que esse ensino não era possível sem um pouco de material, que deveria "compreender objetos in natura, ou amostras e gravuras para tudo o que não se pode conservar ou acondicionar por causa das suas dimensões" (FURET, 2009, p. 244). À organização material da escola também foram dadas orientações, embora se reconhecesse que às vezes era preciso adaptações a "certos" locais e mobílias. Recomendava-se que as salas de aula fossem retangulares e espaçosas, e que fossem usados modelos de bancos e mesas preferencialmente de um só lugar. A mobília contemplava uma estante para o mestre (localizada em cima de um estrado), um quadro negro, um aquecedor (quando necessário), uma pequena pia de água benta, crucifixo e imagens religiosas, sendo conveniente a existência de coleções diversas:

Quadros de leitura, coleção de pesos e medidas, mapas geográficos, quadros murais para o ensino das ciências ou, o que é preferível, amostras de história natural, alguns aparelhos para experiências científicas, biblioteca escolar, segundo a importância da escola. (FURET, 2009, p. 169).

As salas de aulas eram espaços privilegiados onde aconteceria o ensino e, aos materiais, era atribuído um papel importante de auxílio nas lições. Tais orientações, juntamente com as discussões em voga no Brasil no final do século XIX e início do XX, que atribuíam importância às ciências, à educação dos sentidos e às experiências, repercutiram no colégio paulista e incidiram sobre as práticas escolares tanto no ensino primário, quanto no secundário (BOCCHI, 2013, 2017;

\footnotetext{
${ }^{1}$ A primeira versão do Guia das Escolas é de 1853 . A versão consultada é tradução da $4^{\text {a }}$ edição francesa, publicada em 1932.
} 


\section{$(c)$ EY}

MADI FILHO, 2013). Na Revista Echos - publicação anual da instituição destinada aos alunos e familiares - o ensino prático e intuitivo, os gabinetes, museus e laboratórios, assim como os instrumentos de Física e espécimes adquiridos para as aulas, foram mencionados em diversos números. Também nas festas de encerramento a preocupação com o ensino de ciências esteve presente por meios dos discursos proferidos e reproduzidos nas páginas da mencionada revista. Se, por um lado, muitas críticas foram direcionadas ao naturalismo, evolucionismo, materialismo e positivismo, especialmente nas décadas de 1910 e 1920, por outro, foram vários os discursos que procuraram aproximar a religião da ciência.

Alguns sophistas, collegas meus, como o sabeis, gritam em altas vozes, que a religião formadora da sociedade moderna, é impecilho para o progresso da sciencia.

Consultando a historia examinando o seculo XVII um dos mais christãos da idade Moderna, abrindo o livro das mathematicas, deparamos com os Pascal, os Leibniz, os Newton! Vêm-se ainda os Copernico, Kepler e Euler, e todos atestam que a base das sciencias é a religião de Christo, a religião da humanidade.

E porque seria hostil ou indifferente aos progressos da sciencia, o christianismo que n'esses enormes progressos, encontra uma força á sua separação e desenvolvimento? As duas forças - sciencia e religião, unem-se para glorificar a Deus, e formar um magnifico preludio ao hymno da adoração e acção de graças. Trecho do discurso pronunciado pelo aluno João Lima de Figueiredo. (ECHOS, 1913, p. 64).

Ao ensino secundário e às ciências naturais também foram atribuídos importância: o primeiro serviria para formar o espírito, enquanto as ciências naturais foram destacadas pelas inúmeras aplicações que teriam na vida moderna (ECHOS, 1913, p. 65). A defesa do ensino científico não refletiu somente no auditório do colégio, mas vinha ganhando cada vez mais espaço no Brasil desde a segunda metade do século XIX, sendo as mudanças efetuadas no currículo do ensino secundário do Colégio Pedro II um dos indícios disso (LORENZ; VECHIA, 1984; LORENZ, 2003). Ainda que os estudos literários fossem privilegiados, as mudanças curriculares não ocorreram sem disputa e o campo educacional foi marcado por debates sobre a cultura literária e científica.

É importante considerar, ademais, o papel bastante particular que o Colégio Arquidiocesano tinha enquanto instituição particular. Como nos lembra Souza (2008, p. 91), subsistiam dois sistemas paralelos na organização do ensino secundário: de um lado, os estudos regulares realizados nos ginásios mantidos pelos governos estaduais e em poucos colégios privados equiparados e, de outro, os estudos parcelados predominantes nos estabelecimentos particulares. 


\title{
$(\mathrm{cc}) \mathbf{E Y}$
}

Nesse contexto, o Arquidiocesano fazia parte do seleto grupo de colégios particulares equiparados ao Colégio Pedro II, razão pela qual as disciplinas científicas faziam parte do programa, pois uma das exigências era justamente possuir o mesmo programa de ensino da instituição modelar mantida pelo Governo Federal. Como veremos adiante, a direção do colégio empenhou-se em seguir as prescrições governamentais, postura que ocasionou mudanças no espaço escolar e a aquisição de novos materiais de ensino.

\section{O PROCESSO DE EQUIPARAÇÃO E A DEFINIÇÃO DE ESPAÇOS ADEQUADOS AO ENSINO}

Em 1900, o então Colégio Diocesano obteve a equiparação ao Ginásio Nacional ${ }^{2}$, tendo sido o "segundo Collegio do Estado de S. Paulo elevado a essa alta e importantíssima categoria" (SEMINÁRIO EPISCOPAL, 1906, p. 136). A solicitação levou em consideração as exigências do Decreto $n^{\circ} 3.491$ que estabelecia, entre outros aspectos, a existência de laboratórios, gabinetes e aparelhos necessários ao ensino das ciências físicas e naturais (BRASIL, 1899). Tal requisito explicita uma concepção sobre o espaço escolar na qual as salas de aula já não bastavam para que o ensino ocorresse; outros locais diferenciados eram esperados, com formatos e características adequadas ao uso que seria feito.

O relatório de fiscalização que acompanhou o processo de equiparação foi bastante elogioso:

\begin{abstract}
Alem das excellentes condições hygienicas dessa instituição de ensino, o qual funcciona em edificio construido especialmente para educar avultado numero de alumnos, verifiquei que se acha munido de mobilia escolar em tudo conforme com as prescripções da Pedagogia moderna, como tambem de laboratorios, gabinete e apparelhos necessarios para o ensino das sciencias physicas e naturaes, conforme se pode ver na descripção junta. (PROCESSO DE EQUIPARAÇÃO, 1900).
\end{abstract}

Não há informações adicionais sobre os laboratórios e gabinetes, ainda que uma listagem dos aparelhos ateste a variedade de objetos possuídos pela instituição. $O$ primeiro registro fotográfico que ilustra o gabinete de Física e museu foi publicado em 1906, onde se observam quadros parietais, frascos e instrumentos de pequeno e médio porte, sendo os maiores agrupados

\footnotetext{
2 A denominação do colégio sofreu alterações ao longo dos anos. Em 1900, era chamado de Ginásio Nacional e, em 1911, passou a ser chamado Colégio Pedro II, como é referido ao longo desse texto.
}

Rev. Iberoam. Patrim. Histórico-Educativo, Campinas (SP), v. 6, p. 1-28, e020004, 2020. 


\section{$(\mathrm{cc}) \mathrm{EY}$}

ao centro da sala. A organização inicial do acervo é atribuída ao frei Germano D’Annecy e, no ano de publicação da foto, o colégio já possuía bomba de vácuo, máquina de Winchester, máquina Wimshurst, fonte de Heron, modelo anatômico da Maison Deyrolle, além de diversas vidrarias e elementos químicos (BRAGHINI, 2014).

FIGURA 1 - Gabinete de Física e museu do Colégio Diocesano.

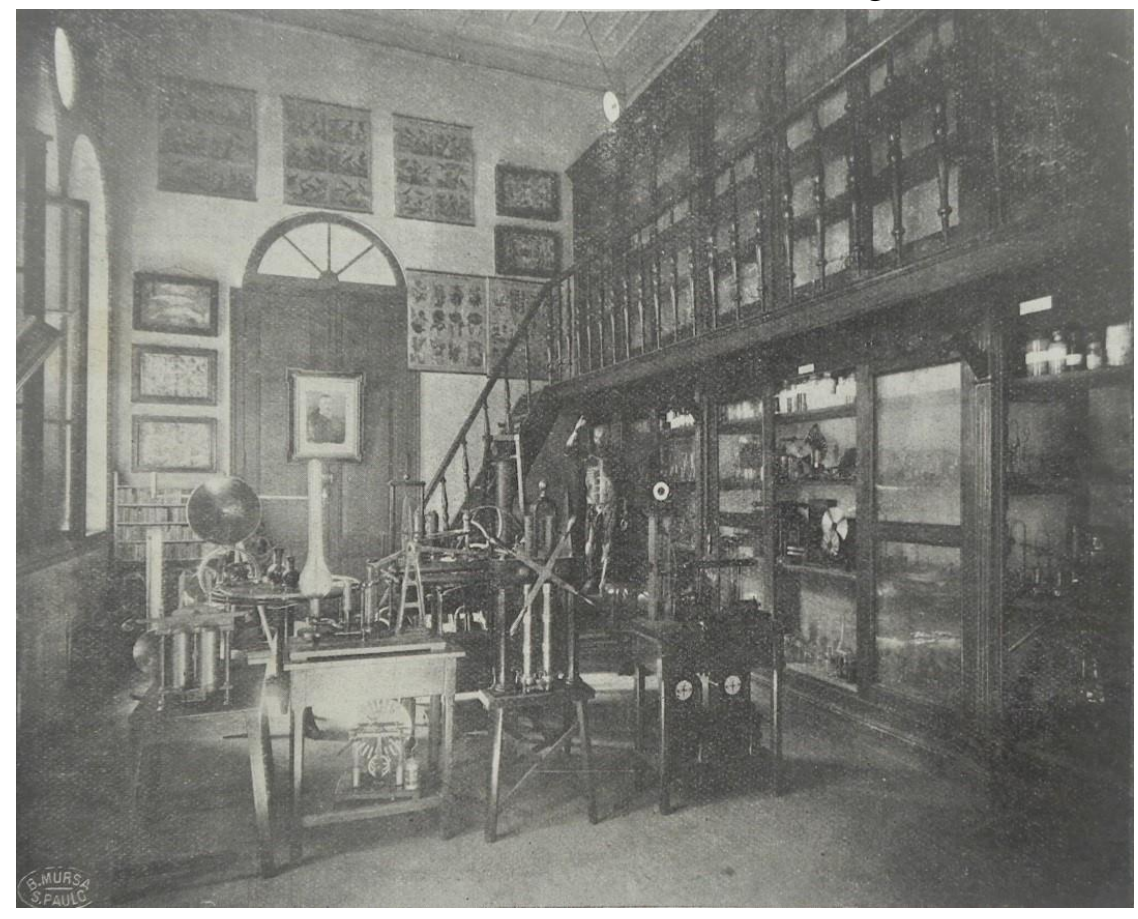

Fonte: Seminário Episcopal (1906, p. 132).

A aquisição de instrumentos e demais objetos para serem usados no ensino trouxe a necessidade de um local para armazená-los. Tal aspecto é igualmente ressaltado pela direção, que afirmava não só realizar visitas e experiências com os alunos nos gabinetes, museus e laboratórios, como também aliar as demonstrações práticas às teóricas e possuir "ricas e preciosas colleções perfeitamente installadas em um local próprio" (LIVRO DE PROVISÕES, 1908, p. 7)³.

A equiparação era um motivo de orgulho e era usada para atestar a qualidade do ensino oferecido. Pedro (2015) destaca que foi uma forma de aumentar o prestígio das instituições católicas, considerando o espaço disputado que aos poucos as escolas estavam se tornando. O título foi mantido até 1911 e o seu fim foi sentido, sendo tema da publicação Echos (1912, p. 29):

\footnotetext{
${ }^{3}$ Restam dúvidas quanto à existência de outros locais usados como gabinete e laboratórios nos primeiros anos do século XX. Neste período, a única foto que se tem mostra uma sala destinada ao museu e gabinete de Física. Somente em 1918 o colégio menciona a inauguração de um laboratório em edifício próprio e isolado (ECHOS, 1918, p. 4).
}

Rev. Iberoam. Patrim. Histórico-Educativo, Campinas (SP), v. 6, p. 1-28, e020004, 2020. 


\section{(cc) EY}

"Suprimiram a equiparação! - Quem fez isso? - O Rivadavia!... Um silencio attonito... Que desgraça!...”. A direção posicionou-se a favor da reforma no ensino secundário, no entanto, apontou que na proposta "houve menos delicadeza e alguma offensa á justiça" (ECHOS, 1912, p. 30).

Outras mudanças sobre o assunto aconteceram nos anos subsequentes. A Reforma Carlos Maximiliano restabeleceu o Colégio Pedro II como modelo e previu a volta da equiparação, mas determinou que nenhum estabelecimento particular de instrução secundária poderia ser equiparado (BRASIL, 1915). Já com a Reforma Francisco Campos, o artigo que tratava dos estabelecimentos equiparados que poderiam expedir os certificados de habilitação incluiu os mantidos pelo governo estadual, municipalidade, associação ou particular (BRASIL, 1931). O Departamento Nacional de Ensino (DNE), ligado ao Ministério da Educação e Saúde Pública, tornou-se responsável por verificar se o estabelecimento atendia a determinadas condições:

I. dispor de instalações, de edifícios e material didático, que preencham os requisitos mínimos prescritos pelo Departamento Nacional do Ensino;

II. ter corpo docente inscrito no Registro de Professores;

III. ter regulamento que haja sido aprovado, previamente, pelo Departamento Nacional do Ensino;

IV. oferecer garantias bastantes de funcionamento normal pelo período mínimo de dois anos. (BRASIL, 1931, art. 45).

Segundo Abreu (2010, p. 294), a inspeção foi uma das medidas complementares adotadas que "pressionaram as escolas a adotar padrões de administração racionalizados e burocratizados" e, juntamente com a definição de um mesmo currículo, programas e critérios de avaliação, indicavam a homogeneização do ensino secundário naquele período.

A publicação Serviço de inspeção dos estabelecimentos de ensino secundário destinada aos inspetores de ensino, traz explicações detalhadas sobre o processo de físcalização. O documento publicado pelo DNE estabeleceu critérios para a classificação dos estabelecimentos tendo em vista a concessão das prerrogativas da inspeção preliminar ou permanente e determinou a classificação das instituições escolares a partir de uma ficha padrão. Os itens avaliados relacionavam-se às condições do edifício, das instalações e do material didático e eram submetidos a notas de 0 a 10. A avaliação considerava cinco divisões principais: 1. local, 2. edifício, 3. instalações, 4. salas de aulas e 5. salas especiais e material didático; ao final, o estabelecimento recebia uma classificação, podendo ou não ser concedida a equiparação. 


\section{$(\mathrm{cc})$ EY}

Em relação ao último aspecto, eram avaliados o auditório ou salão, a biblioteca, o ginásio, a sala de geografia, a sala de Ciências Físicas e Naturais, os laboratórios (de Física, Química e História Natural), a sala de desenho e a sala dos professores e da administração. Quanto à pontuação, Pedro (2014) ressalta que, depois das salas de aula, as salas especiais e materiais didáticos correspondiam ao item mais valorizado pela avaliação, respondendo por 2500 pontos num total de 10 000. E, dentre os itens avaliados nesse quesito, os laboratórios representavam a maior parte da nota, compreendendo 810 pontos.

A pontuação total variava entre 6000 e 10000 e indicava a categoria alcançada pela escola, sendo:

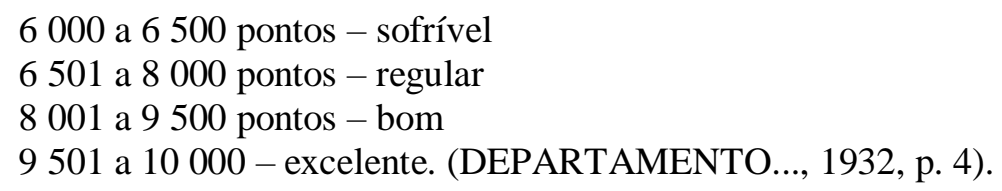

Abaixo de 6000 a escola seria considerada insuficiente. $\mathrm{O}$ mesmo ocorreria se obtivesse pontuação igual ou maior, mas não preenchesse outros sete requisitos, a maioria referente ao espaço e material didático. Dentre eles, era preciso ter:

Sala especial para laboratorio, com área não inferior a 40 metros quadrados, dispondo de mesa para experiências com instalações apropriadas e, pelo menos, $20 \%$ do material constante de cada uma das especificações relativas a Ciencias fisicas e naturais, Fisica, Quimica e Historia natural. (DEPARTAMENTO...,1932, p. 4).

Possuir um laboratório era um requisito mínimo para que as escolas obtivessem o título de equiparação, sendo conveniente que as mesas dos trabalhos fossem instaladas num anfiteatro, podendo os laboratórios serem reunidos no mesmo local (DEPARTAMENTO..., 1932, p. 8). Pelas prescrições, o governo definia o que seria um espaço ideal onde o ensino deveria ocorrer, detalhando o mobiliário e objetos que deveriam compor as chamadas salas especiais. Diferenciava, dessa maneira, as salas de aula regulares dos espaços próprios para as disciplinas científicas, que deveriam possuir arranjos diferenciados.

Mesas e carteiras enfileiradas diante de uma lousa não pareciam condizentes com as expectativas governamentais; uma maneira de impor a perspectiva defendida era regulamentando como deveriam ser os espaços e os materiais que deveriam compô-los. Se isso não garantia a 


\section{$(c)$ EY}

maneira como a aula ocorreria, ao menos estabelecia contornos e uma organização que favoreceria determinadas práticas escolares em detrimento de outras. O fato de o governo sugerir que os laboratórios fossem montados numa sala de anfiteatro pressupunha um jeito de organizar os alunos, os professores e os objetos de forma diferenciada das aulas usuais e, vale dizer, se aproximando de uma tradição já bastante presente em aulas práticas em que os alunos colocavam-se ao redor do professor que, numa posição central, demonstrava ou desenvolvia algum experimento diante de todos, muitas vezes utilizando-se de instrumentos icônicos (BRAGHINI, 2017).

O documento do DNE estabeleceu que as instalações das salas destinadas ao ensino de Ciências Físicas e Naturais, Física e Química deveriam possuir uma mesa de laboratório, pia com torneira e trompa de água, gás ou instalação equivalente e gerador de corrente elétrica. Adicionalmente, esses espaços deveriam ter:

\section{CIÊNCIAS FISICAS E NATURAIS}

Aquario escolar - Terrario escolar - Quadros murais de representações esquematicas, diagramas, maquinismos, etc

FÍSICA

Epidiascopio, com dispositivo para a projeção de experiencias

QUÍMICA

Capela ou dispositivo de exaustão - Alambique. (DEPARTAMENTO..., 1932, p. 14-17).

Já da sala de História Natural, era esperado que tivesse mesas para microscópios e para ensaios pirognósticos, além de Bico de Bunsen ou maçarico (DEPARTAMENTO..., 1932, p. 18). O texto também incluía uma longa lista dos materiais necessários para cada sala. A importância que foi dada ao assunto deve ser considerada juntamente com as demais mudanças instituídas pela reforma Francisco Campos. Souza (2008) identifica a distribuição mais equilibrada entre estudos literários e científicos no curso fundamental e a revitalização do cientificismo como sendo a maior inovação da reforma. A $1^{\mathrm{a}}$ e $2^{\mathrm{a}}$ séries tinham aula de Ciências Físicas e Naturais e a $3^{\mathrm{a}}, 4^{\mathrm{a}}$ e $5^{\mathrm{a}}$ séries de Física, Química e História Natural. As instruções metodológicas do Programa das aulas de Ciências Físicas e Naturais "indicavam a experimentação e a observação de fenômenos naturais e abrangia conteúdos como a atmosfera, calor e luz, água, oxidação e redução, a vida; a terra; magnetismo e eletricidade; os seres vivos; o som; a sociedade" (SOUZA, 2008, p. 158). Já as indicações para o ensino de Física, Química e História Natural destacavam 


\section{$(\mathrm{cc})$ EY}

O aprendizado do conhecimento científico, a importância da experimentação e do uso de laboratórios, a aplicação na vida cotidiana e procedimentos metodológicos que evitassem a memorização e favorecessem a participação dos alunos. (SOUZA, 2008, p. 158).

Dessa maneira, a obrigatoriedade de salas especiais e materiais didáticos estava vinculada a uma proposta que valorizava o ensino das disciplinas científicas e um determinado jeito de ensiná-las. A definição de itens a serem avaliados e a fiscalização das escolas pelos inspetores era uma forma de controle e uma tentativa de ampliar o padrão oferecido pelo Colégio Pedro II. Tão logo a legislação possibilitou, o Colégio Arquidiocesano procurou readquirir a equiparação. A análise do material apresentado pela instituição e a avaliação feita pelos inspetores de ensino elucidam como o processo burocrático interferiu no dia a dia, evidenciando também como o colégio buscou se adequar às normas e realizou mudanças no espaço escolar.

\section{SALAS ESPECIAIS: MODOS DE ENSINAR E APRENDER}

O colégio ficou sob inspeção preliminar a partir de agosto de 1931 e, em 1934, foi promulgado o decreto que concedeu a inspeção permanente e as prerrogativas de estabelecimento livre de ensino secundário (BRASIL, 1934). O processo de equiparação é composto de diversos relatórios contendo descrições e registros fotográficos, fichas de avaliação e correspondências trocadas ao longo dos anos entre o colégio e o governo. Mesmo tendo sido analisado com mais detalhes em outros trabalhos (BOCCHI, 2013; PEDRO, 2014, 2015), ainda restam dúvidas sobre o processo consultado e as pessoas envolvidas. Pouco se sabe, por exemplo, sobre a relação dos inspetores de ensino com a instituição escolar, embora os documentos indiquem uma relação de respeito e o prestígio que os representantes do governo tinham. Há que se considerar, ademais, a possibilidade de a avaliação realizada não ter tido a isenção esperada, como já indicado por Pedro (2014).

A seguir, optamos por priorizar as fotografias usadas no processo de equiparação que evidenciam a disposição das salas de aula e das salas especiais, e explicitam as transformações ocorridas nos dois prédios escolares da instituição: o primeiro, localizado no bairro da Luz, e o segundo, construído no bairro da Vila Mariana, onde permanece até hoje. As fotos, além de terem sido usadas no documento enviado ao governo, foram publicadas em materiais de divulgação da escola, tais como a Revista Echos, uma série de cartões portais e um prospecto de divulgação da 


\section{(c) $) \mathrm{EY}$}

instituição, indicando a centralidade da imagem como registro e propaganda dos preceitos defendidos pela moderna pedagogia.

\section{O colégio no bairro da Luz.}

$\mathrm{Na}$ planta do colégio, quatro salas destinadas ao ensino das disciplinas científicas são identificadas: uma de Química, uma de Física e História Natural, e duas pequenas salas destinadas a um museu. Ainda que ausente na planta, o processo de equiparação também indica a existência de uma sala de Ciências Físicas e Naturais, o que nos faz acreditar que outros espaços cumpriram essa função, não havendo um local exclusivo para tal fim.

FIGURA 2 - Quinta série / Vista parcial do gabinete de Física.

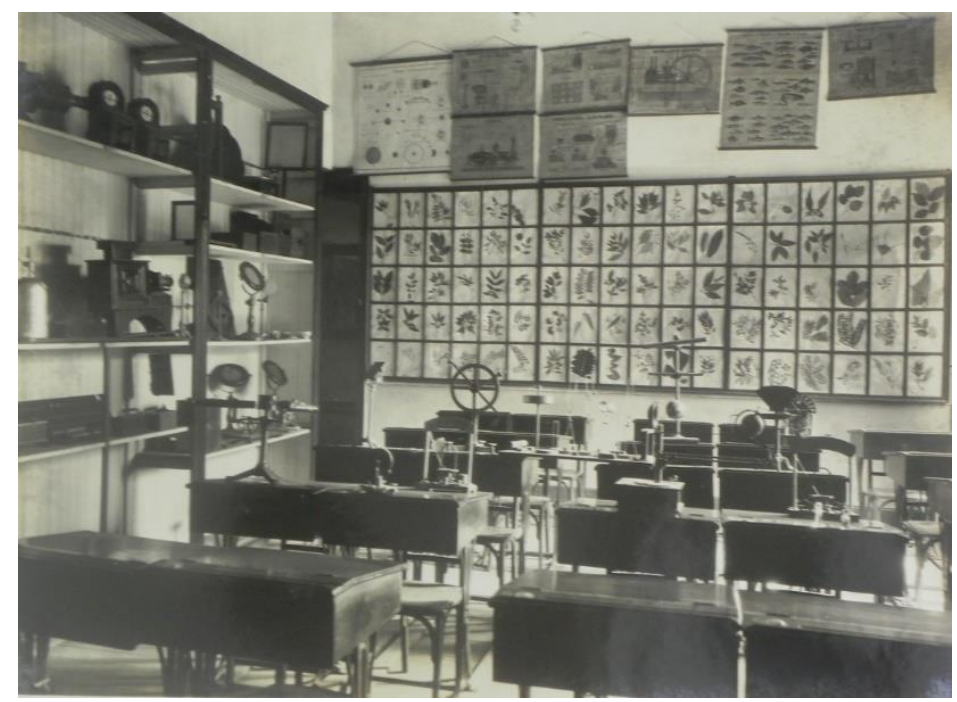

Fonte: Processo de Equiparação (1933).

A quinta série ginasial, além de sala de aula, abrigou o herbário permanente e parte do gabinete de Física. Acima do herbário, e longe do alcance das mãos e da vista dos alunos, há quadros parietais ${ }^{4}$ cujos títulos em francês indicam a origem estrangeira do material, assim como os conteúdos abordados: Mappa cosmographico, Propagation Rectiligne de la Lumiere Reflexion

\footnotetext{
4 “O quadro parietal é um material didático usado para a transmissão de conhecimentos escolares. É uma representação gráfica de determinados conteúdos escolares numa superfície plana. São chamados de parietais, pois são pendurados nas paredes ou em outros dispositivos para serem observados por todos os alunos simultaneamente" (FARIA, 2017, p. 22-23).
} 


\section{$(\mathrm{cc}) \mathbf{E Y}$}

Refraction, Meteorologie, Machine a vapeur e, abaixo, Locomotive e Sonnorie Electrique telegrafe Morse.

Encostada a parede há uma estante com instrumentos de Física, dentre eles alguns espelhos. Já os outros instrumentos foram colocados em cima das mesas ao fundo da sala, maneira que tanto dava destaque, como possibilitava que fossem observados de todos os lados. Se supormos que essa disposição era mantida em alguns momentos das aulas, é possível inferir uma mudança de perspectiva por parte dos alunos, já que as peças deixavam de ser vistas lado a lado nas estantes e passavam a ser contempladas tridimensionalmente. Ademais, o fato de os objetos estarem em cima das mesas e em estantes sem vidro ou outra proteção colocava o manuseio como uma possibilidade - fosse ele um desvio à regra ou um convite do professor.

A Figura 2 retrata outra perspectiva da mesma sala de aula em que também se nota a variedade de objetos expostos. Há outras duas estantes menores, à direita e à esquerda, onde ficam alguns instrumentos de Física. Em uma das mesas é possível observar um microscópio e outros dois objetos em destaque - uma garça maguari e um gato mourisco taxidermizados, que ainda hoje compõem o acervo do colégio. Há ainda quadros parietais apoiados na lousa e fixados na parede acima das janelas, em meio a símbolos religiosos: o quadro da esquerda é sobre anfíbios e os apoiados na lousa trazem a representação de vermes, pássaro e crustáceos.

FIGURA 3 - Quinta série / Vista parcial do gabinete de Física.

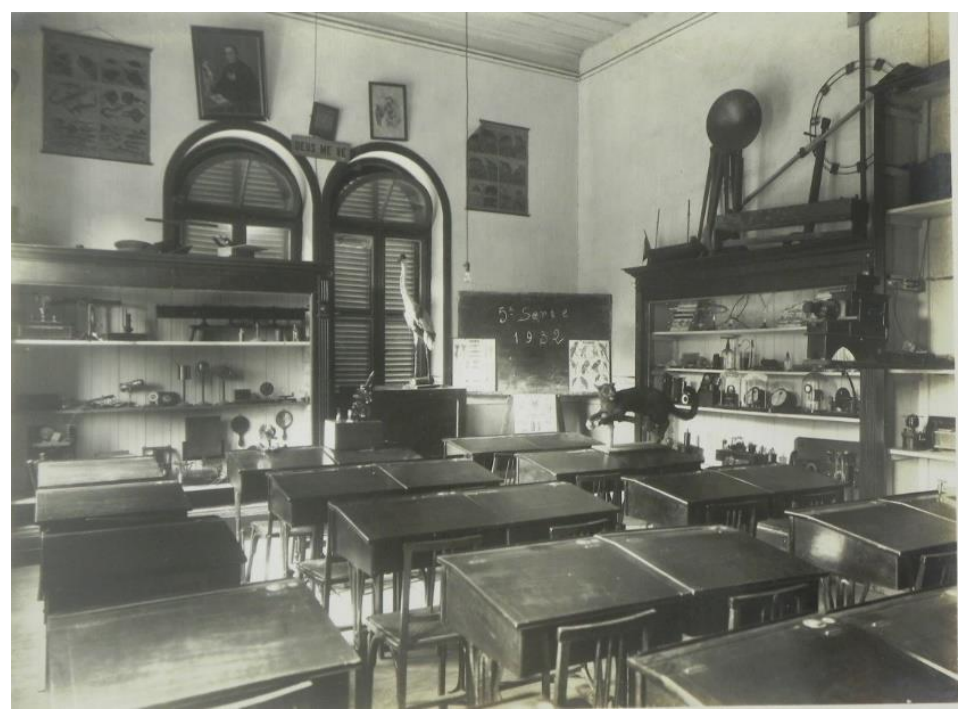

Fonte: Processo de Equiparação (1933). 


\section{$(\mathrm{cc})$ EY}

Outro gabinete de Física (Figura 4) é retratado nas fotos que acompanham o relatório. Sem colocar em questão os instrumentos que compunham os acervos, o que chama a atenção é a configuração de espaços tão distintos sob o mesmo nome. Em um caso, o gabinete compunha uma parte de uma sala de aula onde ficavam estantes repletas de instrumentos, juntamente com quadros parietais e um herbário. No outro, há uma sala ampla, com estantes ao longo da parede e mesas ao centro, possibilitando maior circulação de pessoas e uma disposição que privilegiava os instrumentos. Além de local de armazenamento, é possível imaginar que ali as aulas ocorressem de modo diferente de uma sala de aula em que os alunos permaneciam sentados, de frente para uma lousa.

FIGURA 4 - Um dos gabinetes de Física.

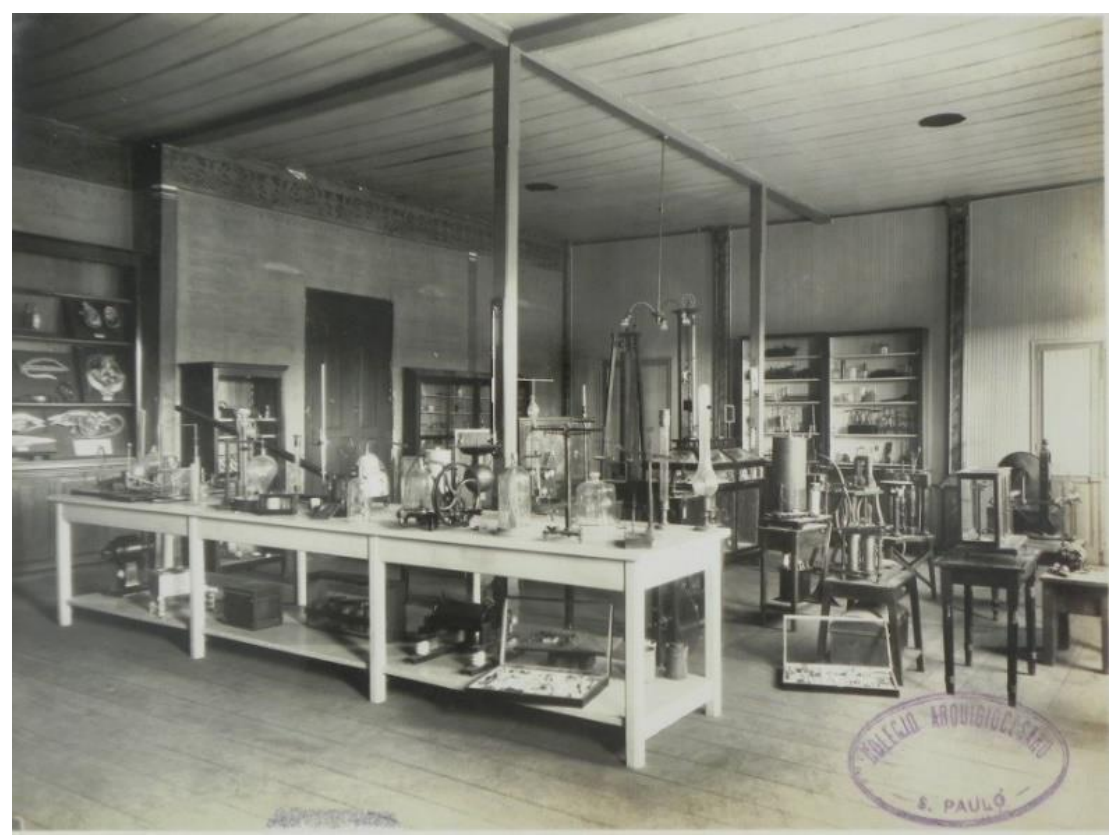

Fonte: Processo de Equiparação (1933)

A sala retratada na Figura 4 parece ter tido uma dupla função, sendo usada também como gabinete de História Natural (Figura 5), considerando a semelhança entre as salas e a planta do edifício, que indica um mesmo local para ambas atividades. O arranjo interno igualmente possibilita circular ao redor das mesas, observar e manusear os objetos com relativa facilidade. 


\section{$(\mathrm{cc}) \mathrm{EY}$}

FIGURA 5 - Colégio Arquidiocesano. Um dos gabinetes de História Natural. 1932.

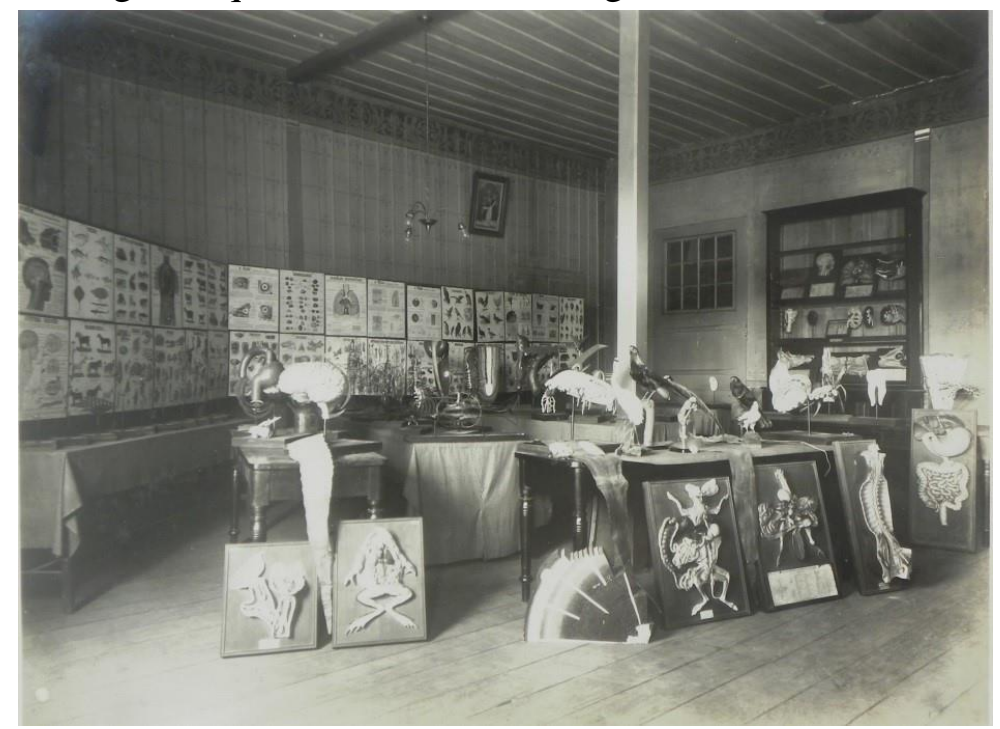

Fonte: Processo de Equiparação (1933).

Outro gabinete de História Natural, também chamado de museu, tinha uma organização bastante diferente. Nas figuras 6 e 7 sobressaem as estantes onde ficavam armazenados diversos objetos - é possível observar aves taxidermizadas, um modelo esfolado de corpo humano e um esqueleto (Figura 6), além de chifres, frascos, livros, quadros parietais e um objeto que se assemelha a uma lanterna mágica, instrumento de projeção bastante difundido nas instituições escolares (Figura 7). Dentre as aves, está a garça maguari, também presente na Figura 3. Esses dois registros dão pistas dos usos que se fazia do gabinete e da sala de aula: no primeiro caso, o objeto encontra-se em uma estante sem portas ou vidro e junto com diversos materiais dispostos sem aparente ordem; no segundo, foi colocado em cima de uma mesa na frente da sala de aula, em posição de destaque. Aparentemente, esse gabinete se aproximava mais de um local para guardar determinados materiais escolares, enquanto a sala de aula se configurava como um espaço de prática, possibilitando outra disposição do objeto e, por que não, outras possibilidades de uso. 


\section{(cc) EY}

FIGURA 6 - Gabinete de História Natural.

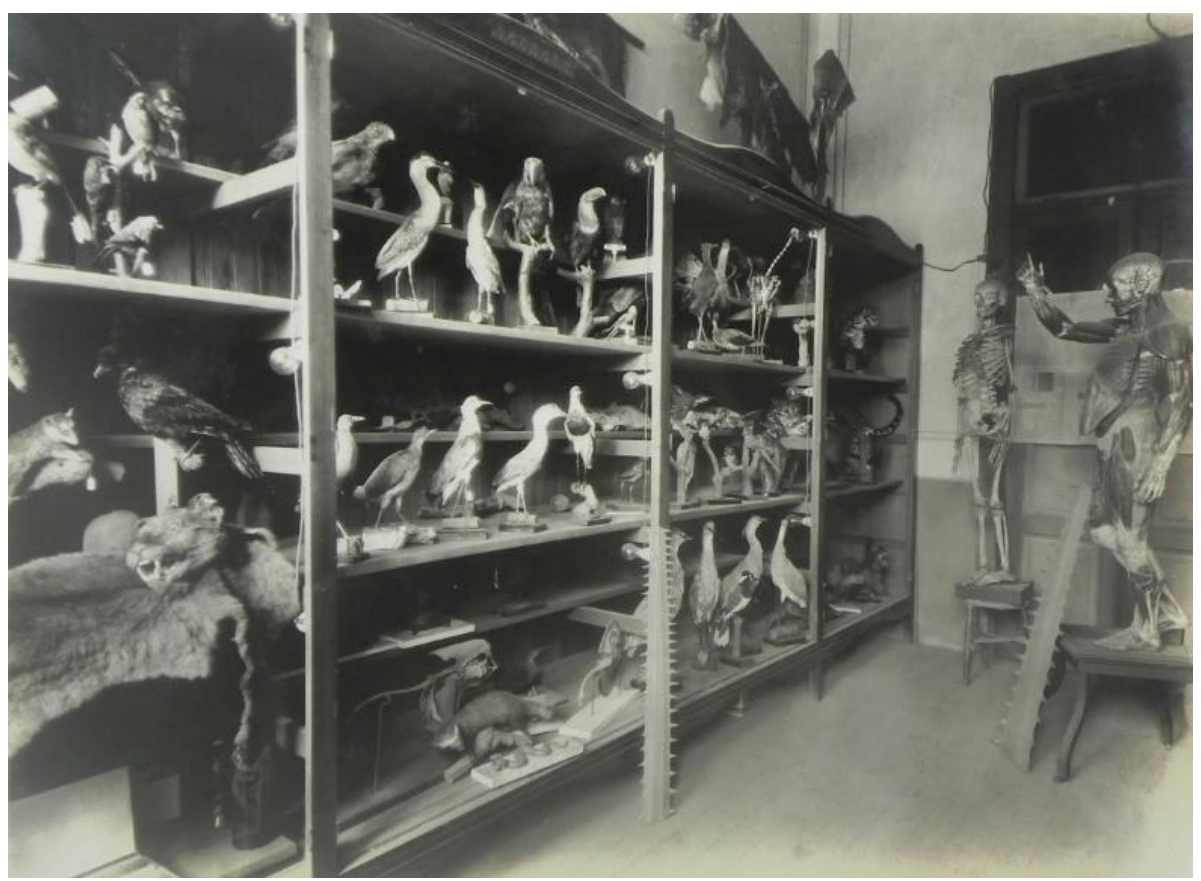

Fonte: Processo de Equiparação (1933).

FIGURA 7 - Gabinete de História Natural

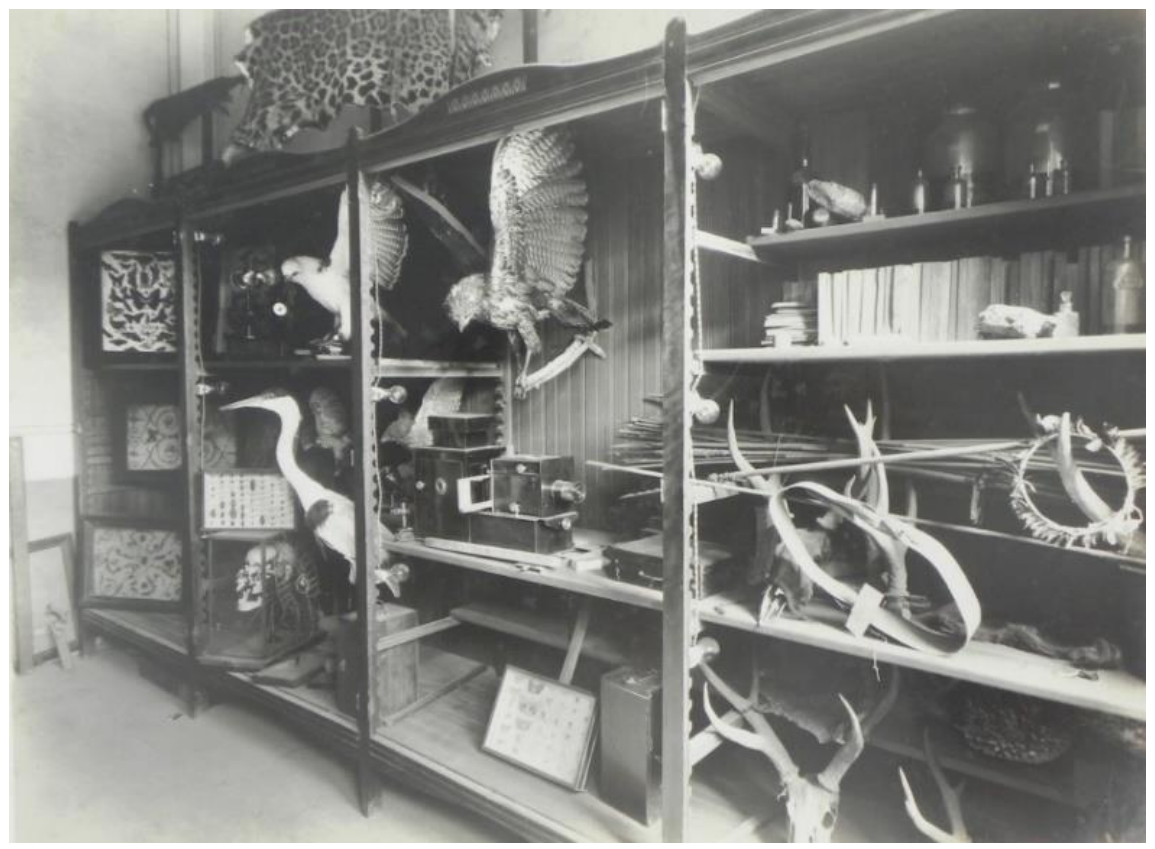

Fonte: Processo de Equiparação (1933) 


\section{(cc) EY}

Já o laboratório de Química foi organizado especialmente para o desenvolvimento de atividades práticas. A Figura 8 destaca a bancada de trabalho e seis rapazes durante um experimento. Eles seguram frascos e tubos de ensaio e estão com um semblante sério, atentos ao que estavam fazendo. Na montagem em frente ao estudante de gravata borboleta, observa-se uma retorta, material usado para destilação - o material é aquecido, se transforma e libera gases. Atrás da mesa há uma estante com frascos de diversos tamanhos e uma lousa, onde parece estar descrita uma reação química, juntamente com um desenho.

FIGURA 8 - Laboratório de Química / Mesa de manipulação

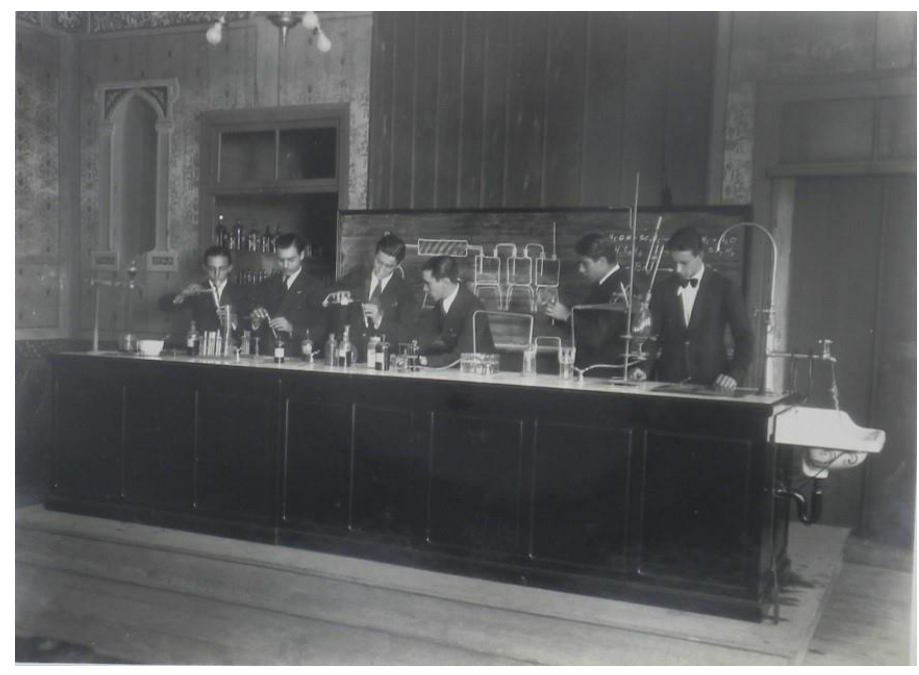

Fonte: Processo de Equiparação (1933)

A organização dos espaços estava atrelada às especificidades das disciplinas escolares. Meloni (2010) destaca as necessidades diferentes nas aulas - em Física se estudava fenômenos que podiam ser demonstrados com aparelhos, já o estudo químico da matéria comumente envolvia a transformação. No primeiro caso, os aparelhos poderiam ser montados em salas de aulas comuns; no segundo,

Eram necessários materiais como reagentes, instrumentos de aquecimento, água corrente etc para serem montados e manipulados que só podiam existir em um local onde se pudesse executar o labor sobre a matéria, ou seja, o laboratório". (MELONI, 2010, p. 108). 


\section{$(\mathrm{cc})$ EY}

As fotos não só compuseram o processo de equiparação, como também foram publicadas na revista do colégio, no mesmo número em que foi divulgado um relato bastante elogioso do inspetor de ensino originalmente destinado ao DNE:

Percorri demoradamente os Gabinetes de Physica, Chimica, Historia Natural, orçados em cerca de cem contos de reis.

Todo o apparelhamento exigido pelo Departamento Nacional do Ensino ali se encontra.

Nos laboratorios de chimica, os educados [sic] podem, com a maxima facilidade, preparar hydrogenio, caracterizar acidos, bases, saes; os cathions chumbo, mercurio, prata...

Encontram-se á mão, todos os apparelhos necessarios para qualquer experiencia de physica.

De modo todo especial, attrahiram-me a attenção as finissimas peças de anatomia, que enriquecem o museu de Historia Natural, assim como o 'Herbario Exposição' que o ornamenta. (ÉCOS, 1932, n.p.).

Neste caso, o texto foi tão favorável que serviu até mesmo de propaganda, pois dava credibilidade ao trabalho desenvolvido. Os comentários positivos condizem com a avaliação obtida no processo de equiparação, na qual a sala de Ciências Físicas e Naturais e os laboratórios obtiveram nota máxima. Em relação à sala de Ciências Físicas e Naturais, a mesa armada para o desenvolvimento de trabalhos experimentais, assim como a facilidade que os alunos teriam para estudar experimentalmente, foram ressaltados. Foi destacada, igualmente, a mesa de laboratório de Física aparelhada para as experiências indicadas para os alunos das últimas duas séries e as mesas do Gabinete de História Natural. O laboratório de Química foi o mais elogiado:

O gabinete de quimica acha-se localisado no $2^{\circ}$ pavimento em ponto regularmente afastado das salas de aula. Foi montado com esmero. A Diretoria do Estabelecimento nada poupou paraque [sic] os alunos pudessem estudar praticamente e com o maximo proveito a quimica.

Em sala ampla, muito bem iluminada, foi armada grande meza de experiencias, provida de todos os aparelhos e objetos necessarios, com gavetões e armarios, torneiras para agua corrente e, pias (ha tres), tomadas de corrente eletrica, tomadas de gaz. (PROCESSO DE EQUIPARAÇÃO, 1933, p. 74).

A instituição escolar atendeu às expectativas governamentais e, na avaliação final, obteve a classificação bom. 


\section{(cc) $\mathbf{E Y}$}

O colégio na Vila Mariana

O novo prédio foi um marco na história do colégio, sendo construído com grande suntuosidade - as novas dependências seriam amplas, modernas e contemplariam laboratórios e museus (ECHOS, 1929, p. 51). De acordo com a planta interna, o edifício tinha quatro andares e uma construção anexa, com dois andares e um porão. No segundo pavimento ficava o laboratório de Química, junto ao anfiteatro. As duas salas ao lado eram ocupadas pelos gabinetes de Ciência, e o museu ficava localizado no pavimento superior do prédio anexo.

Outras duas fichas de classificação indicam a fiscalização realizada pelo governo, uma em 1934 e outra em 1940. No primeiro caso, a nova sede recebeu elogios, mas obteve uma avaliação semelhante a anterior. Em relação à sala de Ciências Físicas e Naturais, observou-se que a aparelhagem seguia as prescrições do DNE e, no tocante aos laboratórios, consta:

Dois optimos quer pelas installações quer pelo material. Completa-os um magnifico amphiteatro com apparelho para projecções luminosas. Um curioso dispositivo faz descer sobre o local de experiencias chimicas uma cortina de vidro que isola os espectadores do executante. (PROCESSO DE EQUIPARAÇÃO, 1940, p. 4).

A ficha de classificação que acompanha o documento, no entanto, atribui notas que não são tão favoráveis - a sala de Ciências e o laboratórios obtiveram pontuação 7. O parecer, apesar de positivo, apresenta ressalvas: “Algumas salas especiais talvez não atinjam o elevado standard do resto do edifício, o que entretanto não se pode julgar com exatidão por ser pouco minucioso o relatório sôbre êste ponto" (PROCESSO DE EQUIPARAÇÃO, 1940, p. 14).

$\mathrm{O}$ fato de as salas especiais e os materiais didáticos terem obtido notas mais baixas do que na avaliação anterior chama a atenção, tendo em vista os elogios do inspetor, as notas máximas obtidas previamente e as melhorias implementadas pelo colégio. Nos anos subsequentes, entretanto, a direção conseguiu reverter a situação e obteve a categoria excelente - a sala de ciências e os laboratórios receberam 10. Reconheceu-se que o colégio era uma casa modelar de ensino, dotada de todas as adaptações sugeridas pela evolução pedagógica daquele tempo preconizadas pelas experiências já realizadas nos países de adiantada cultura (PROCESSO DE EQUIPARAÇÃO, 1940, p. 33). O relatório é bastante descritivo e traz detalhes das novas dependências. Surpreende, contudo, o item referente às salas especiais, pois a descrição é 


\section{$(c)$ EY}

exatamente a mesma do relatório que acompanhou a primeira ficha de classificação, de 1933. Ainda que mudanças significativas tenham ocorrido e que as notas tenham sido alteradas, o texto se manteve igual, o que gera dúvidas sobre o processo de fiscalização.

As mudanças que o gabinete de Física sofreu são evidentes nas fotografias (Figura 9). O novo local, claro e iluminado, tem uma grande mesa onde os instrumentos poderiam ser manipulados e observados. Ao fundo da sala, observa-se um amplo armário envidraçado com quatro divisões principais, onde encontram-se dispostos diversos aparelhos.

FIGURA 9 - Colégio Arquidiocesano. Aspecto parcial dos mostruários do Gabinete de Física / Parte do Gabinete de Física. 1940

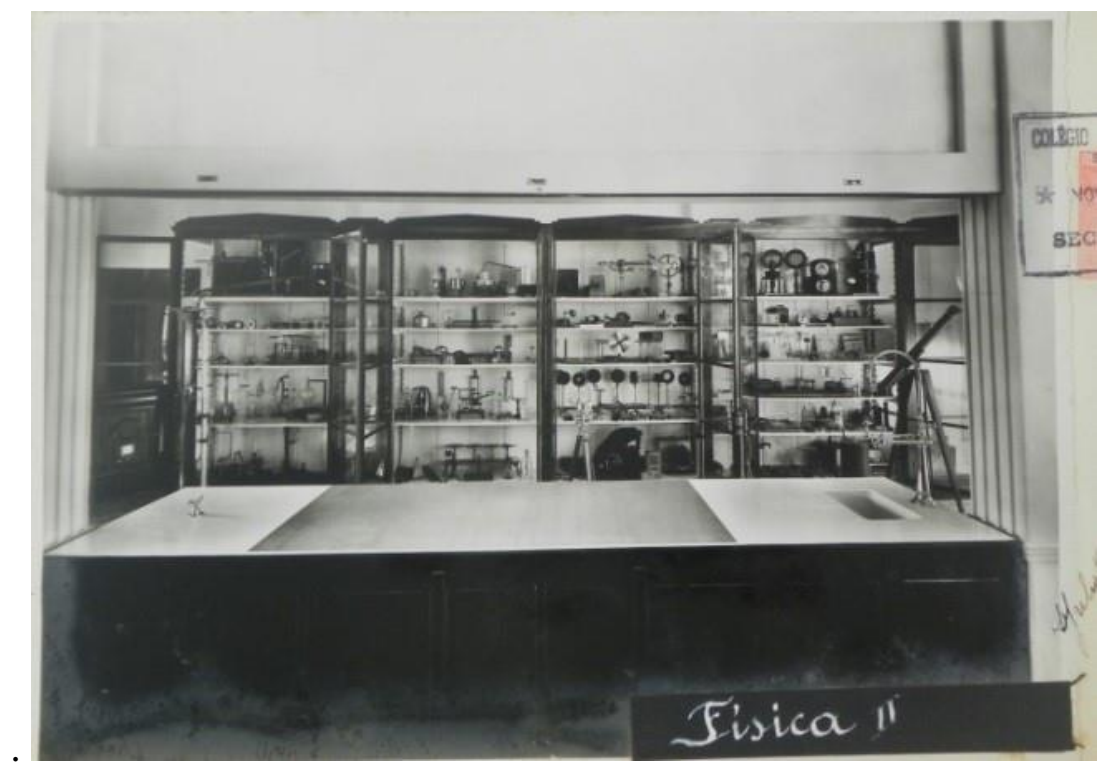

Fonte: Processo de Equiparação (1940)

O laboratório de Química (Figura 10) guarda semelhanças com o do prédio antigo da instituição. A mesa de manipulação continua central na disposição da sala e é possível observar diversos armários com os materiais da área de ensino. A estante de madeira, contudo, foi substituída por armários envidraçados, que protegiam mais, ao mesmo tempo em que mantinham a visibilidade dos itens. O local foi destacado em um catálogo do Colégio: "De paredes inteiramente brancas e alízar de azulejos da mesma côr, mesas para experiências, estantes e mostruários com farto material, o Gabinete de Química constitue ambiente agradável e convidativo" (PROCESSO DE EQUIPARAÇÃO, 1940, n.p.). 


\section{(cc) EY}

FIGURA 10 - Laboratório de Química

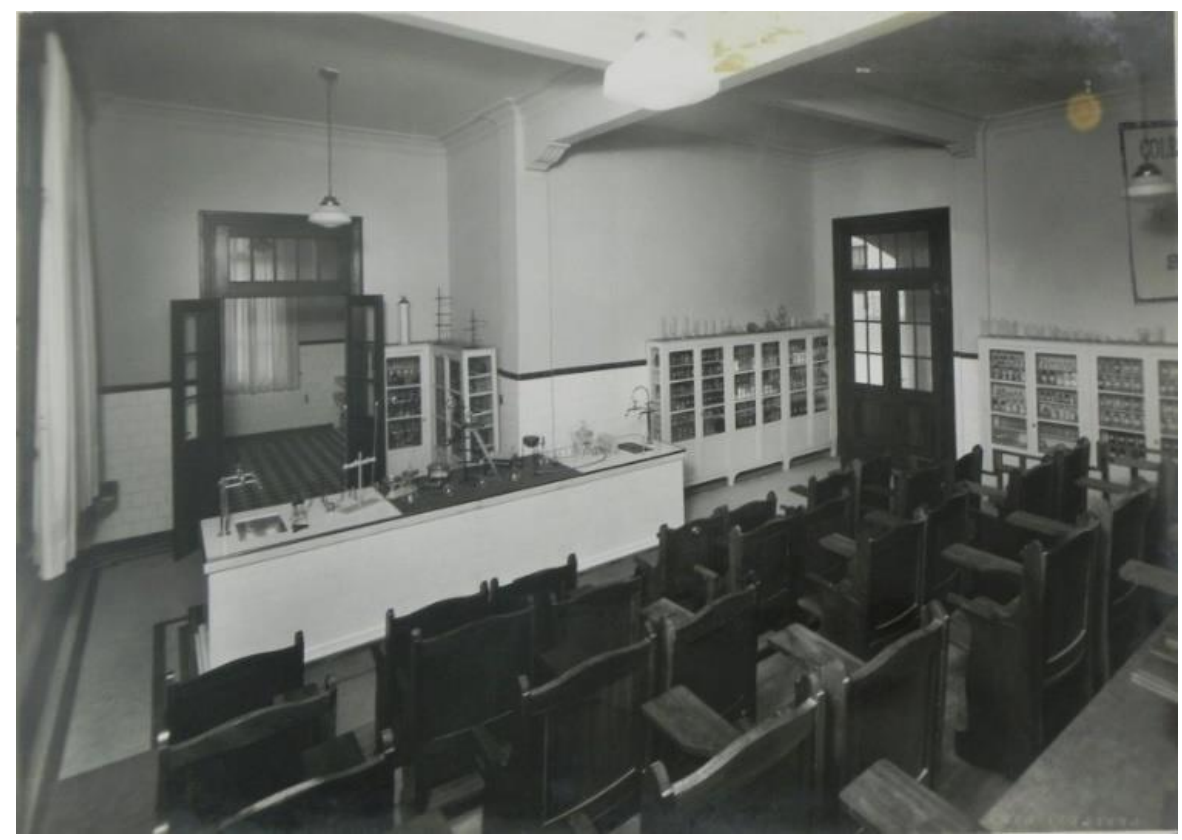

Fonte: Processo de Equiparação (1940)

$\mathrm{O}$ anfiteatro era um ponto de destaque: "Uma das principais exigências do Departamento de Ensino, os laboratórios merecem cuidado todo especial. Para gabinetes de física e química nada mais se pode exigir" (PROCESSO DE EQUIPARAÇÃO, 1940, n.p.). A menção ao órgão do governo no prospecto evidencia sua importância ao estabelecer os critérios que respaldaram as mudanças efetuadas no prédio do colégio.

Outro espaço destinado ao ensino das disciplinas científicas que passou por transformações foi o museu de História Natural. Nas figuras 11 e 12, observam-se diversos materiais mantidos em armários envidraçados, entre eles aves taxidermizadas, minérios, modelos de órgãos, quadros parietais, esqueleto humano, entre outros. 


\section{$(\mathrm{cc})$ EY}

FIGURA 11 - Museu de História Natural

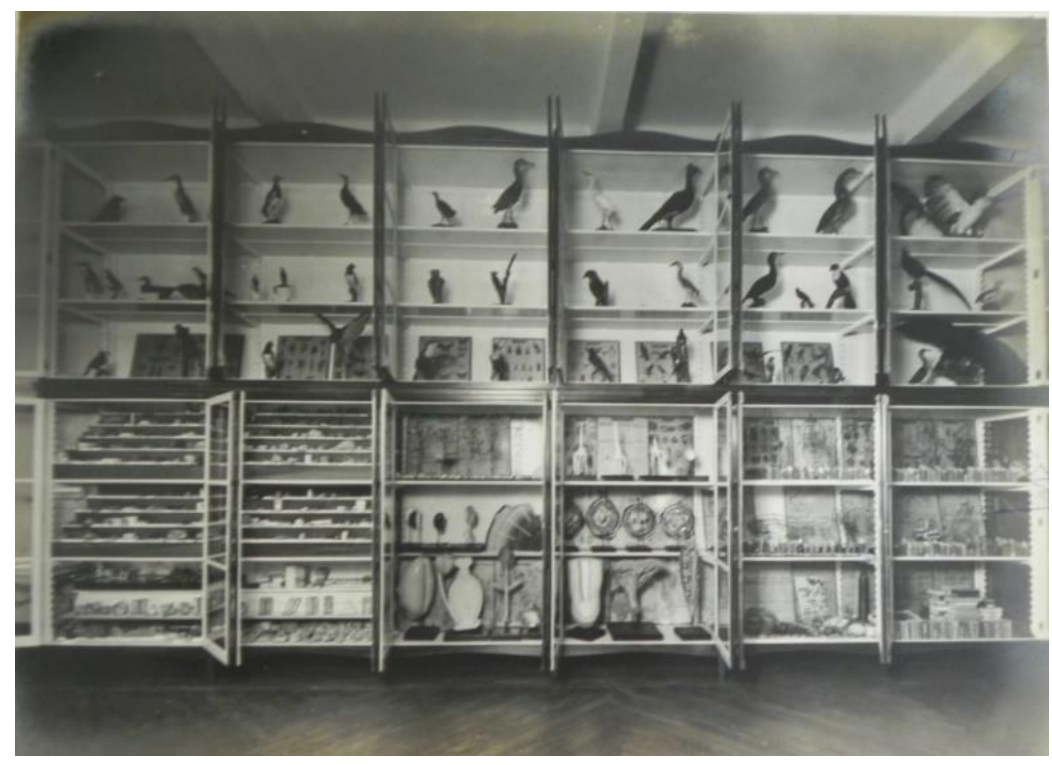

Fonte: Processo de Equiparação (1940)

FIGURA 12 - Museu de História Natural

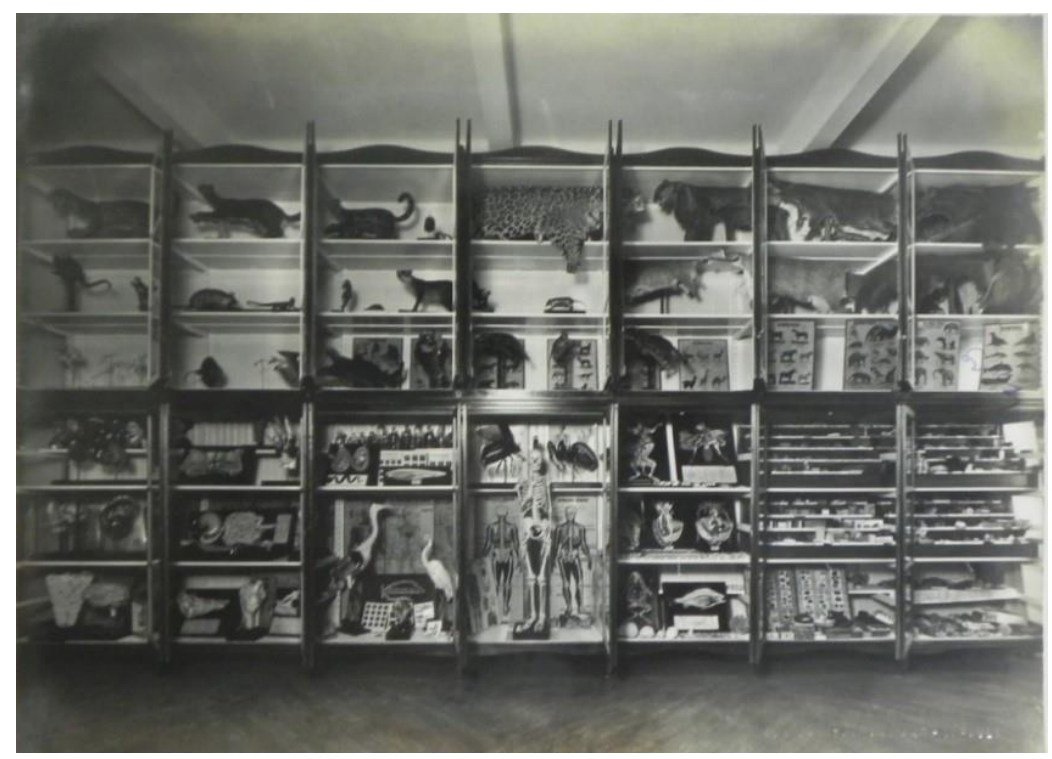

Fonte: Processo de Equiparação (1940)

É perceptível a mudança em como os artefatos foram mantidos e organizados nas prateleiras - enquanto nas figuras 6 e 7 a impressão é que estavam amontoados e que faltava espaço para mantê-los, nas figuras 11 e 12 transparece a ideia de ordem e classificação. O nome de museu 


\section{$(c)$ EY}

combina com essa configuração, pois parece que os objetos estão lá armazenados, sendo possível a observação e apreciação. Não há uma mesa, como no laboratório de Física ou Química, que indique alguma atividade prática por parte dos professores ou alunos.

FIGURA 13 - Colégio Arquidiocesano. Museu de História Natural. 1940.

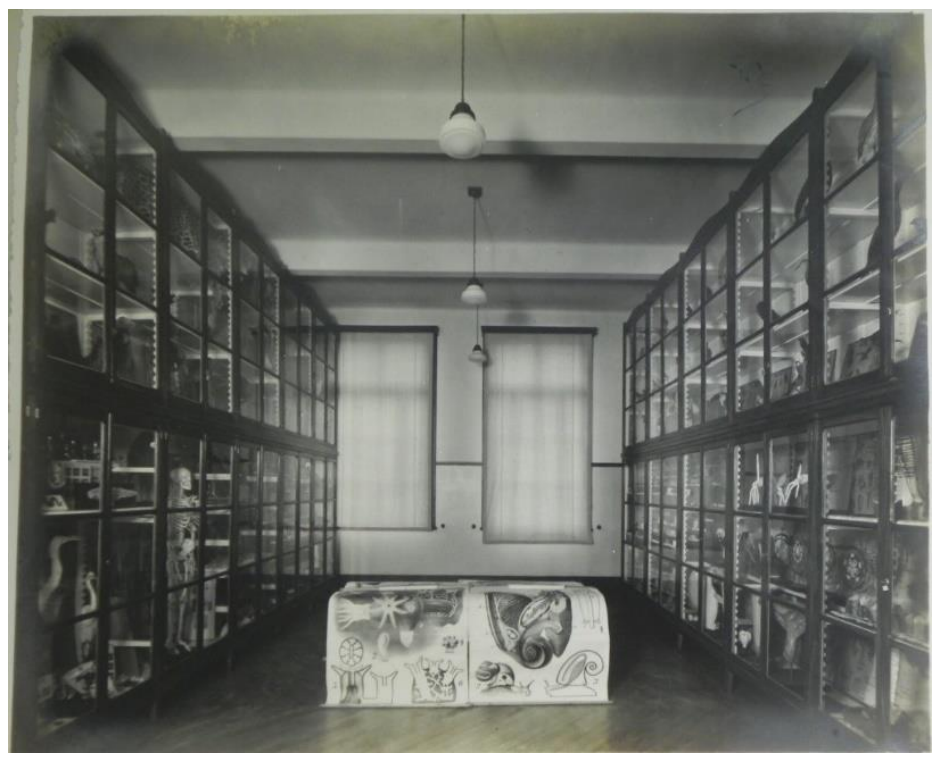

Fonte: Processo de Equiparação (1940)

Ao considerarmos as fotos, concordamos com Vinão (1993-1994, p. 62) quando afirma que é na sala de aula, o núcleo por excelência da atividade instrucional, onde a análise histórica mostra a relação entre a disposição no espaço de pessoas e objetos e o sistema ou método de ensino seguido. Ainda que o nosso olhar não privilegie as salas de aula regulares, acreditamos que o estudo das salas especiais no período abarcado explicita concepções sobre a educação, o ensino de ciências e o papel dos professores e alunos.

A definição de locais próprios para o ensino de Química, Física e História Natural no colégio e as transformações pelos quais passaram ao longo dos anos evidenciam a importância crescente das disciplinas científicas, assim como das práticas e dos fazeres característicos das áreas. Em relação à sala de Ciências Físicas e Naturais, as fotos indicam que não havia um local exclusivo para esse uso, o que nos leva a crer que os demais recintos cumpriam esse fim quando necessário. É certo que esses locais tinham características distintas das tradicionais salas de aula - o mobiliário, os demais objetos e sua disposição no espaço marcam uma diferenciação do arranjo usual, pois, 


\section{(cc) $\mathrm{EY}$}

justamente, era esperado outro jeito de se relacionar e de se movimentar diante daquelas configurações.

\section{CONSIDERAÇÕES FINAIS}

A análise dos documentos relacionados ao Colégio Arquidiocesano mostra como a instituição modificou os espaços ao longo dos anos, ampliou os locais vinculados ao ensino de ciências e adquiriu novos materiais didáticos. As práticas científicas não poderiam ocorrer de qualquer jeito, nem em qualquer lugar, e as salas de aulas convencionais já não combinavam com um ensino que pretendia ser prático e experimental.

Na instituição paulista, o título de equiparação ao Colégio Pedro II foi bastante valorizado e, desde o início do século XX, foi tido como um diferencial e uma forma de atestar a qualidade da educação oferecida. A partir de 1908, quando os Irmãos Maristas assumem a direção, o Guia das Escolas também passou a oferecer orientações quanto ao espaço e materiais escolares, de acordo com uma proposta que ressaltava a intuição e a educação dos sentidos.

No colégio, inicialmente havia uma sala para abrigar o Gabinete de Física e Museu. Aos poucos, modificações foram feitas e novos espaços foram criados, atendendo às regulamentações governamentais relativas ao ensino secundário. Progressivamente, também ocorreu uma separação das coleções de acordo com as disciplinas escolares e os espaços tornaram-se cada vez mais especializados. A equiparação cumpriu um papel importante ao tentar padronizar um modelo de educação e definir o que seriam espaços escolares adequados.

As mudanças e melhorias empreendidas pela direção do colégio eram divulgadas à comunidade escolar e, certamente, o museu e os laboratórios destacaram-se. Fotos e descrições dos locais exaltavam a realização de atividades condizentes com a pedagogia moderna. $\mathrm{O}$ ensino de ciências foi marcado espacialmente - salas foram criadas e organizadas com mobiliários e objetos diferenciados, possibilitando outras formas de circulação, de interação e ensino. Se retomarmos a ideia de Viñao com a qual começamos o texto de que o espaço não é neutro, podemos inferir que as transformações efetuadas no Colégio Arquidiocesano incidiram não somente na arquitetura escolar, mas no próprio educar. 


\section{REFERÊNCIAS}

ABREU, Geysa Spitz Alcoforado de. A homogeneização do ensino secundário na década de 1930: estratégias de eficiência, racionalidade e controle. Educar em Revista, Curitiba, n. spe2, p. 291-301, 2010.

ASSIS, Paula Maria de. Educação dos sentidos e a formação do cidadão e cristão católico no Guide des Écoles: o modo marista de educar. In: BRAGHINI, Katya, MUNAKATA, Kazumi, TABORDA DE OLIVEIRA, Marcus Aurelio (Org.). Diálogos sobre a história da educação dos sentidos e das sensibilidades. Curitiba: Ed. UFPR, 2017. p. 283-307.

BOCCHI, Luna Abrano. A configuração de novos locais e práticas pedagógicas na escola: o museu escolar, os laboratórios e gabinetes de ensino do Colégio Marista Arquidiocesano de São Paulo (1908-1940). 2013. 135 f. Dissertação (Mestrado em Educação) - Pontifícia Universidade Católica, São Paulo, 2013.

BOCCHI, Luna Abrano. Os locais destinados ao ensino de ciências no Colégio Marista Arquidiocesano de São Paulo (1908-1940). In: BRAGHINI, Katya, MUNAKATA, Kazumi, TABORDA DE OLIVEIRA, Marcus Aurelio (Org.). Diálogos sobre a história da educação dos sentidos e das sensibilidades. Curitiba: Ed. UFPR, 2017. p. 93-113.

BRAGHINI, Katya. The collection of scientific instruments of the Colégio Marista Arquidiocesano Museum, São Paulo: origins, context and significance. In: GRANATO, M.; LOURENÇO, M. (Org.). Scientific Instruments in the History of Science: studies in transfer, use and preservation. Rio de Janeiro: Museu de Astronomia e Ciências Afins, 2014. p. 277-296.

BRAGHINI, Katya. O que os objetos científicos nos contam sobre a educação dos sentidos, na passagem do século XIX para o século XX? In: BRAGHINI, Katya, MUNAKATA, Kazumi, TABORDA DE OLIVEIRA, Marcus Aurelio (Org.). Diálogos sobre a história da educação dos sentidos e das sensibilidades. Curitiba: Ed. UFPR, 2017. p. 67-91.

BRASIL. Decreto n 3.491, de 11 de novembro de 1899. Disponível em: http://www2.camara.leg.br/legin/fed/decret/1824-1899/decreto-3491-11-novembro-1899-520771publicacaooriginal-1-pe.html. Acesso em: 27 maio 2020.

BRASIL. Decreto no 11.530, de 18 de março de 1915. Disponível em: http://www2.camara.leg.br/legin/fed/decret/1910-1919/decreto-11530-18-marco-1915-522019republicacao-97760-pe.html. Acesso em: 27 maio 2020.

BRASIL. Decreto n 19.890, de 18 de abril de 1931. Disponível em: http://www2.camara.leg.br/legin/fed/decret/1930-1939/decreto-19890-18-abril-1931-504631publicacaooriginal-141245-pe.html. Acesso em: 27 maio 2020. 


\section{$(c)$ EY}

BRASIL. Decreto no 23.742, de 15 de janeiro de 1934. Disponível em: https://www2.camara.leg.br/legin/fed/decret/1930-1939/decreto-23742-15-janeiro-1934-515754publicacaooriginal-1-pe.html. Acesso em: 27 maio 2020.

COLÉGIO ARQUIDIOCESNO DE SÃO PAULO. Livro de provisões. 1908.

COLÉGIO ARQUIDIOCESANO DE SÃO PAULO. Échos. São Paulo, n. 3, 1912.

COLÉGIO ARQUIDIOCESANO DE SÃO PAULO. Echos. São Paulo, n. 5, 1913.

COLÉGIO ARQUIDIOCESANO DE SÃO PAULO. Echos. São Paulo, n. 10, 1918.

COLÉGIO ARQUIDIOCESANO DE SÃO PAULO. Echos. São Paulo, n. 21, 1929.

COLÉGIO ARQUIDIOCESANO DE SÃO PAULO. Écos. São Paulo, n. 24, 1932. COLÉGIO ARQUIDIOCESANO DE SÃO PAULO. Processo de equiparação do Colégio Arquidiocesano de São Paulo. São Paulo, 1933.

COLÉGIO ARQUIDIOCESANO DE SÃO PAULO. Écos. São Paulo, n. 32, 1939.

COLÉGIO ARQUIDIOCESANO DE SÃO PAULO. Processo de equiparação do Colégio Arquidiocesano de São Paulo. São Paulo, 1940.

COLÉGIO DIOCESANO. Processo de equiparação do Colégio Diocesano. São Paulo, 1900.

DEPARTAMENTO NACIONAL DE ENSINO. Serviço de inspeção dos estabelecimentos de ensino secundário. Rio de Janeiro: Imprensa Nacional, 1932.

ESCOLANO BENITO, Agustín. Tiempos y espacios para la escuela: ensayos históricos. Madrid: Biblioteca Nueva, 2000. 253 p.

FARIA, Joana Borges de. Os quadros parietais nas escolas do Sudeste brasileiro (1890-1970). 2017. 332 f. Tese (Doutorado em Educação) - Pontifícia Universidade Católica, São Paulo, 2017.

FURET, Jean-Baptiste et al. Guia das Escolas para uso nas casas dos Pequenos Irmãos de Maria: documento do $2^{\circ}$ Capítulo Geral do Instituto Marista. Brasília: UMBRASIL, 2009. 251 p.

GONÇALVES, Rita de Cássia. A arquitetura como uma dimensão material das culturas escolares. In: GASPAR DA SILVA, Vera Lúcia; PETRY, Marilia Gabriela (Org.). Objetos da escola: espaços e lugares da constituição de uma cultura material escolar (Santa Catarina - século XIX e XX). Florianópolis: Insular, 2012. p. 27-62.

KOSSOY, Boris. Fotografia \& História. São Paulo: Ateliê Editorial, 2009. 184 p.

LAWN, Martin; GROSVERNOR, Ian (Ed.). Materialities of Schooling: Design, Technology, Objects, Routines. Oxford: Symposium Books, 2005. 217 p. 
LORENZ, Karl M.; VECHIA, A. Comparação diacrônica dos estudos de ciências e humanidades no currículo secundário brasileiro. Ciência e Cultura, São Paulo, v. 36, n. 1, p. 32-35, 1984.

LORENZ, Karl M. O ensino de ciências e o Imperial Collegio Pedro II: 1838-1889. In: VECHIA, A; CAVAZOTTI, M. A. (Org.) A escola secundária: modelos e planos (Brasil, séculos XIX e XX). São Paulo: Annablume, 2003. p. 49-61.

MADI FILHO, José Maurício. Animais taxidermizados como materiais de ensino em fins do século XIX e começo do século XX. 2013. 143 p. Dissertação (Mestrado em Educação) Pontifícia Universidade Católica, São Paulo, 2013.

MELONI, Reginaldo Alberto. Saberes em Ciências Naturais: o ensino de Física e Química no Colégio Culto à Ciência de Campinas - 1873-1910. 2010. 211 f. Tese (Doutorado em Educação) - UNICAMP, Campinas, 2010.

PEDRO, Ricardo Tomasiello. História da equiparação do Colégio Marista Arquidiocesano de São Paulo ao Colégio Pedro II (1900-1940). 2014. 176 f. Dissertação (Mestrado em Educação)

- Pontifícia Universidade Católica, São Paulo, 2014.

PEDRO, Ricardo Tomasiello. História da equiparação do Colégio Marista Arquidiocesano de São Paulo ao Colégio Pedro II (1900-1940). In: VIII CONGRESSO BRASILEIRO DE HISTÓRIA DA EDUCAÇÃO. Anais [...]. Maringá, 2015.

SEMINÁRIO EPISCOPAL. Publicação Commemorativa do $1^{\circ}$ Quinquagenario da fundação do Seminario Episcopal de S. Paulo. São Paulo, 1906.

SILVA, Vera Lucia Gaspar; PETRY, Marília Gabriela (Org.). Objetos de escola: espaços e lugares de constituição de uma cultura material escolar (Santa Catarina - séculos XIX e XX). Florianópolis: Insular, 2012. 231 p.

SOUZA, Rosa Fátima de. História da Cultura Material Escolar: um balanço inicial. In: BENCOSTTA, Marcus Levy Albino (Org.). Culturas escolares, saberes e práticas educativas: itinerários históricos. São Paulo: Cortez, 2007. p. 163-189.

SOUZA, Rosa Fátima de. História da organização do trabalho escolar e do currículo no Século XX: ensino primário e secundário no Brasil. São Paulo: Cortez, 2008. 319 p.

VIÑAO FRAGO, Antonio. Do espaço escolar e da escola como lugar: propostas e questões. In: VIÑAO FRAGO, Antonio; ESCOLANO, Agustín. Currículo, espaço e subjetividade: a arquitetura como programa. Rio de Janeiro: DP\&A, 1998. p. 59-139.

Recebido em: 04 de dezembro de 2019 Aceito em: 02 de junho de 2020 